\title{
Akibat Hukum Berlakunya Putusan MK Nomor 18/PUU/V/2007 Terhadap Usulan DPR Dalam Pembentukan Pengadilan Ham Ad Hoc
}

\section{Legal Effects of the Applicability of Court Decision Number 18 / PUU / V / 2007 Against the House's Proposal in Establishment of the Ad Hoc Ham Court}

\author{
Xavier Nugraha ; Maulia Madina; Ulfa Septian Dika \\ Fakultas Hukum Universitas Airlangga
}

xavier.nugraha-2015@fh.unair.ac.id;mamaulia09@gmail.com; ulfa.septiandika@gmail.com

Telp. 0822-574-88-276

\begin{abstract}
ABSTRAK
Artikel ini merupakan kajian konseptual terkait usulan DPR sebagai langkah awal dalam pembentukan Pengadilan HAM Ad Hoc. Dalam penjelasan Pasal 43 ayat (2) UndangUndang Nomor 26 Tahun 2000 Tentang Pengadilan Hak Asasi Manusia, dijelaskan bahwa usulan DPR tersebut didasarkan pada dugaan telah terjadinya pelanggaran HAM berat yang locus dan tempus delictinya terjadi sebelum diundangkannya Undang-Undang Pengadilan Hak Asasi Manusia. Frasa dugaan dalam penjelasan tersebut menimbulkan problematika karena melakukan dugaan tersebut adalah fungsi penyelidikan sesuai Pasal 1 angka 5 Undang-Undang Nomor 26 Tahun 2000. DPR seolah menjalankan fungsi untuk melakukan penyelidikan dalam yang seharusnya merupakan kewenangan Komnas HAM sesuai Pasal 18 Undang-Undang Nomor 26 Tahun 2000. Hal ini tumpang tindih kewenangan DPR dan Komnas HAM. Pasca Putusan MK Nomor 18/PUU/V/2007, DPR wajib untuk mengajukan usulan pengadilan HAM Ad Hoc , setalah adanya dugaan pelanggaran HAM berat sebelum diundangkannya Undang-Undang Pengadilan Hak Asasi Manusia oleh Komnas HAM
\end{abstract}

\section{Kata Kunci: DPR; Komnas HAM; Pengadilan HAM Ad Hoc}

\section{ABSTRACT}

This article is a conceptual study related to the House of Representatives proposal as an initial step in the establishment of the Ad Hoc Human Rights Court. In the explanation of Article 43 paragraph (2) of Law Number 26 Year 2000 concerning the Human Rights Court, it was explained that the House of Representatives proposal was based on the alleged occurrence of gross human rights violations that had locus and temporal delays before the promulgation of the Human Rights Court Law. The alleged phrase in the explanation raises a problem because making such an assumption is a function of investigation in accordance with Article 1 number 5 of Act Number 26 of 2000. The House of Representatives seems to carry out a function to conduct investigations which should be the authority of the National Human Rights Commission in accordance with Article 18 of Law Number 26 Year 2000. This authoriy overlaps the authority of the DPR and the National Human Rights Commission. After the Constitutional Court Decision Number 18 / PUU / V / 2007, the House of Representatives was obliged to submit an Ad Hoc Human Rights court proposal, following the 
alleged gross human rights violations before the promulgation of the Human Rights Court Law by the National Commission of Human Rights

\section{Keyword: House of Representatives; National Commission of Human Rights; Ad Hoc Human Rights Court}

\section{PENDAHULUAN}

Dalam pembukaan Undang-Undang Dasar Negara Republik Indonesia Tahun 1945 (UUD NRI Tahun 1945) telah tercantum tujuan negara Indonesia yaitu melindungi segenap bangsa Indonesia dan seluruh tumpah darah Indonesia. ${ }^{1} \mathrm{Hal}$ ini dapat diartikan bahwa negara memiliki tanggung jawab untuk melindungi Hak Asasi Manusia (HAM) setiap warga negaranya. Perlindungan negara terhadap HAM diwujudkan dalam pengaturan tersendiri mengenai HAM dalam BAB XA UUD NRI Tahun 1945, pembentukan Undang-Undang Nomor 39 Tahun 1999 Tentang Hak Asasi Manusia (UU No. 39 Tahun 1999), dan pembentukan Undang-Undang Nomor 26 Tahun 2000 Tentang Pengadilan Hak Asasi Manusia (UU No. 26 Tahun 2000). ${ }^{2}$

Dalam UU No. 39 Tahun 1999, HAM diartikan sebagai seperangkat hak yang melekat pada hakikat dan keberadaan manusia sebagai mahluk Tuhan Yang Maha Esadan merupakan anugrah-Nya yang wajib dihormati, dijunjung tinggi dan dilindungi oleh negara hukum, Pemerintahan, dan setiap orang demi kehormatan serta perlindungan harkat dan martabat manusia. ${ }^{3}$ Sementara itu, pelanggaran HAM diartikan sebagai setiap perbuatan yang dilakukan oleh seseorang atau kelompok orang, termasuk aparat negara, baik dengan sengaja atau pun tidak disengaja, atau kelalaian yang secara melawan hukum, mengurangi, menghalangi, membatasi, atau mencabut HAM seseorang atau kelompok orang yang dijamin oleh undang-undang ini dan tidak mendapatkan atau dikhawatirkan tidak akan memperoleh penyelesaian hukum yang adil berdasarkan mekanisme hukum yang berlaku. ${ }^{4}$ Dengan demikian, jika merujuk pada definisi tersebut, sesungguhnya makna pelanggaran HAM dalam UU No. 39 Tahun 1999 adalah pelanggaran terhadap prinsip-prinsip HAM. ${ }^{5}$

Dalam UU No. 39 Tahun 1999, dapat ditemukan diferensiasi terkait pelanggaran HAM tersebut, yakni pelanggaran HAM dan pelanggaran HAM berat. ${ }^{6}$ Adanya diferensiasi tersebut memiliki konsekuensi yuridis, dimana jika terjadi pelanggaran HAM berat, maka akan diadili melalui pengadilan HAM. Meskipun terdapat diferensiasi tersebut, namun UU No. 39 Tahun 1999 tidak memberikan pengaturan lebih lanjut mengenai konsep pelanggaran HAM berat. Mengenai Pelanggaran HAM berat tersebut, dapat ditemukan di dalam UU No.

1 Tomy Michael, "Korelasi Alinea Keempat Undang-Undang Dasar NRI Tahun 1945 Dengan Pemikiran Immanuel Kant”, Jurnal Hukum Samudra Keadilan 11,no.2 (Desember 2016): 2.

${ }^{2}$ Nunik Nurhayati, "Quo Vadis Perlindungan Hak Asasi Manusia Dalam Penyelesaian Pelanggaran HAM Berat Masa Lalu Melalui Jalur Non Yudisia,” Jusrisprudence 6, no. 2 ( September 2016): 149.

${ }^{3}$ Undang-Undang Nomor 39 Tahun 1999 tentang Hak Asasi Manusia (Lembaran Negara Tahun 1999 Nomor 165, Tambahan Lembaran Negara Nomor 3886), Ps 1 angka 1.

${ }^{4}$ Undang-Undang Nomor 39 Tahun 1999 tentang Hak Asasi Manusia (Lembaran Negara Tahun 1999 Nomor 165, Tambahan Lembaran Negara Nomor 3886), Ps 1 angka 6.

${ }^{5}$ Nunik Nurhayati, Op. Cit., h. 150.

6 Dalam Undang-Undang Nomor 39 Tahun 1999 terdapat terminologi pelanggaran HAM dan pelanggaran HAM berat, dimana untuk pelanggaran HAM berat akan diselesaikan melalui Pengadilan HAM, lebih lanjut lihat Undang-Undang Nomor 39 Tahun 1999 tentang Hak Asasi Manusia (Lembaran Negara Tahun 1999 Nomor 165, Tambahan Lembaran Negara Nomor 3886), Ps 104 
26 Tahun 2000. Dalam Pasal 1 angka 2 UU No. 26 Tahun 2000 pelanggaran HAM yang berat adalah pelanggaran hak asasi manusia sebagaimana dimaksud dalam Undang-undang ini. ${ }^{7}$ Secara sistematis, mengenai konsep pelanggaran HAM yang berat yang dimaksud dapat ditemukan dalam Pasal 7 UU No. 26 Tahun 2000 yang menyebutkan katagori kejahatan yang merupakan pelanggaran HAM berat, yakni kejahatan genosida dan kejahatan terhadap kemanusiaan.

Pelanggaran HAM yang berat merupakan extra ordinary crimes dan berdampak secara luas, baik tingkat nasional maupun internasional dan bukan merupakan tindak pidana yang diatur di dalam KUHP, serta menimbulkan kerugian baik materil maupun immateril yang mengakibatkan perasaan tidak aman, baik terhadap perseorangan maupun masyarakat sehingga perlu segera dipulihkan dalam mewujudkan supremasi hukum untuk mencapai kedamaian, ketertiban, ketentraman, keadilan, dan kesejahteraan bagi seluruh masyarakat Indonesia. ${ }^{8}$ Oleh karena itu, untuk mengadili pelanggaran HAM berat diperlukan suatu pengadilan khusus sehingga dibentuklah pengadilan HAM. Latar belakang terbentuknya Pengadilan HAM berdasarkan pada Risalah Rapat Pansus RUU tentang Pengadilan HAM pada tanggal 2 November 2000 adalah untuk menyelesaikan masalah pelanggaran HAM yang berat dan mengembalikan keamanan dan perdamaian di Indonesia perlu dibentuk Pengadilan HAM. $^{9}$

Dibentuknya UU Pengadilan HAM tanggal 23 November 2000 tidak terlepas dari suatu keadaan yang menghendaki agar pelaku pelanggaran HAM yang berat diadili. Karena itu, dalam bagian menimbang telah disebutkan : (a) bahwa hak asasi manusia merupakan hak dasar yang secara kodrati melekat pada diri manusia bersifat universal dan langgeng, olen karena itu harus dilindungi, dihormati, dipertahankan, dan tidak boleh diabaikan, dikurangi, atau dirampas oleh siapapun; (b) bahwa untuk ikut serta memelihara perdamaian dunia dan menjamin pelaksanaan hak asasi manusia serta memberi perlindungan, kepastian, keadilan, dan perasaan aman kepada perorangan ataupun masyarakat, perlu segera dibentuk suatu Pengadilan HAM untuk menyelesaikan pelanggaran HAM yang berat sesuai dengan ketentuan Pasal 104 Ayat (1) UU No. 39 Tahun 1999; (c) bahwa pembentukan Pengadilan HAM untuk menyelesaikan pelanggaran HAM yang berat telah diupayakan oleh Pemerintah berdasarkan Perpu No. 1 Tahun 1999 tentang Pengadilan HAM yang dinilai tidak memadai, sehingga tidak disetujui oleh DPR RI menjadi undang-undang, dan oleh karena itu Perpu tersebut perlu dicabut. ${ }^{10}$

Dalam mengadili kasus pelanggaran HAM berat di Pengadilan HAM, terdapat 2 (dua) klasifikasi, yaitu Pengadilan HAM dan Pengadilan HAM Ad Hoc. Pengadilan HAM adalah pengadilan khusus yang dibentuk untuk mengadili pelaku pelanggaran hak asasi manusia yang berat yang terjadi di masa yang akan datang (prospektif), sedangkan Pengadilan HAM Ad Hoc, tujuan pembentukannya adalah sebagai bagian dari upaya penyelesaian persoalan

${ }^{7}$ Undang-Undang Nomor 26 Tahun 2000 tentang Pengadilan Hak Asasi Manusia (Lembaran Negara Tahun 2000 Nomor 208, Tambahan Lembaran Negara Nomor 4026), Ps 1 angka 2.

${ }^{8}$ R. Wiyono, Pengadilan Hak Asasi Manusia, Kencana, Jakarta, 2006, h. 170.

${ }^{9}$ Penjelasan Undang-Undang Nomor 26 Tahun 2000 tentang Pengadilan Hak Asasi Manusia (Lembaran Negara Tahun 2000 Nomor 208, Tambahan Lembaran Negara Nomor 4026).

${ }^{10}$ Undang-Undang Nomor 26 Tahun 2000 tentang Pengadilan Hak Asasi Manusia (Lembaran Negara Tahun 2000 Nomor 208, Tambahan Lembaran Negara Nomor 4026). 
transitional justice, yaitu mengadili pelaku pelanggaran hak asasi manusia yang berat yang terjadi di masa lalu (retrospektif). ${ }^{11}$

Pengadilan HAM Ad Hoc adalah sebuah kebutuhan, yaitu sebagai salah satu sarana untuk menyelesaikan pelanggaran HAM yang berat yang terjadi di masa lalu yang tidak mungkin diselesaikan atau diadili melalui Pengadilan HAM karena meskipun ratione materiae-nya sama, Pengadilan HAM hanya mempunyai kewenangan mengadili pelanggaran HAM yang berat yang terjadi setelah diundangkannya UU No. 26 Tahun 2000. Bahwa semangat pembentukan Pengadilan HAM Ad Hoc adalah untuk menghapuskan impunitas (impunity), yaitu sikap membiarkan pelanggaran- pelanggaran HAM yang berat yang terjadi di masa lampau tanpa penyelesaian. ${ }^{12}$ Oleh karena itu, pembentukan Pengadilan HAM Ad Hoc adalah bagian dari upaya untuk menegakkan prinsip "tiada kejahatan yang dibiarkan berlalu demikian saja tanpa hukuman" (aut punere aut de dere, nullum crimen sine poena), yang merupakan asas penting dalam negara hukum yang demokratis. ${ }^{13}$

Pelanggaran HAM berat yang pernah terjadi di Indonesia sebelum diundangkannya UU No. 39 Tahun 1999 dan UU No. 26 Tahun 2000 diantaranya kasus Tanjung Priok (1984), kasus Timtim (1999) dan kasus Abepura (2000), Kasus kerusuhan Mei (1998), kasus Talangsari (1989), Peristiwa 1965, kasus penembakan misterius, kasus Wasior-Wamena, Kasus penghilangan orang secara paksa 1997/1998, dan kasus Trisakti (Semanggi I dan Semanggi II). ${ }^{14}$ Pelanggaran HAM berat tersebut dapat diselesaikan berdasarkan pengaturan yang terdapat dalam ketentuan Pasal 43 Ayat (1) dan Ayat (2) UU No. 26 Tahun 2000 yang menyatakan bahwa peristiwa pelanggaran HAM berat yang terjadi sebelum berlakunya UU No. 26 Tahun 2000, diperiksa dan diputus oleh Pengadilan HAM Ad Hoc yang dibentuk melalui Keputusan Presiden berdasarkan usul DPR terhadap suatu peristiwa tertentu. ${ }^{15}$

Hal ini menimbulkan problematika, karena dalam penjelasan Pasal 43 ayat (2) UU No. 26 Tahun 2000 dijelaskan bahwa:

"Dalam hal Dewan Perwakilan Rakyat Republik Indonesia mengusulkan dibentuknya Pengadilan HAM ad hoc, Dewan Perwakilan Rakyat Republik Indonesia mendasarkan pada dugaan telah terjadinya pelanggaran hak asasi manusia yang berat yang dibatasi pada locus dan tempos delicti tertentu yang terjadi sebelum diundangkannya Undang-undang ini. (penebalan dari penulis)."

Dari penjelasan Pasal 43 ayat (2) UU No. 26 Tahun 2000 tersebut seolah memberikan legitimasi kepada DPR untuk mengajukan usulan pembentukan Pengadilan HAM Ad Hoc, ketika DPR menduga sendiri adanya pelanggaran HAM berat di masa lampau. Padahal, ketika kita melihat fungsi DPR dalam Pasal 20A UUD NRI Tahun 1945, tidak ada satupun fungsi DPR yang memiliki korelasi dalam fungsi pro justitia. ${ }^{16}$ Ketika DPR yang merupakan political representation, yang mana sarat akan kepentingan partai politik diberikan fungsi

${ }^{11}$ Fadli Andi Natsif, 'Perspektif Keadilan Transisional Penyelesaian Pelanggaran Hak Asasi Manusia Berat', Jurisprudentie, Vol. 3, No. 2, Desember 2016, h. 89.

12 Daniel Hutagalung, 'Negara dan Pelanggaran HAM Masa Lalu : Tuntutan Pertanggungjawaban versus Impunitas', Jurnal Dignitas, Vol. 3, No. 1, 2005, h. 18

13 Jonathan Aprilino Soegijanto, “Asas Retroaktif Yang Berlaku Dalam Undang-Undang Peradilan HAM," Legal Standing 2, no. 1 (12 Maret 2018): 31.

${ }^{14}$ Nunik Nurhayati, Op. Cit., h. 150.

${ }^{15}$ Nunik Nurhayati, Op. Cit., h. 150.

16 Dalam Pasal 20A UUD UUD NRI Tahun 1945, fungsi DPR adalah fungsi anggaran,legislasi, dan pengawasan 
mengajukan usulan pembentukan pengadilan HAM Ad Hoc, berdasarkan dugaan DPR semata, maka ditakutkan DPR akan menggunakan fungsi tersebut untuk menyerang lawanlawan politiknya. Sebaliknya, jika pelaku HAM berat di masa lalu itu adalah kawan politiknya, maka ditakutkan ketika pembentukan pengadilan HAM Ad Hoc harus diinisiasi oleh dugaan DPR, maka DPR akan berdalil bahwa tidak ada dugaan akan pelanggaran HAM. Contohnya, kasus Tragedi Semanggi 1 dan 2, DPR beranggapan tidak ada kasus pelanggaran HAM di sana, padahal Komnas HAM menyimpulkan terdapat bukti-bukti permulaan yang cukup telah terjadi pelanggaran HAM berat dalam peristiwa tersebut dengan 50 orang perwira TNI/Polri yang diduga terlibat dalam kasus tersebut. ${ }^{17}$ Dari penjelasan tersebut, dapat disimpulkan, bahwa kata 'dugaan' dalam penjelasan Pasal 43 ayat (2) UU No. 26 Tahun 2000 dapat menimbulkan ketidakpastian hukum (rechtsonzekerheid) dan bertentangan dengan Pasal 28D ayat (1) UUD UUD NRI Tahun 1945.

Namun, ketentuan pembentukan Pengadilan HAM Ad Hoc melalui usul DPR yang didasarkan oleh dugaan DPR sendiri itu diajukan constitutional review kepada Mahkamah Konstitusi (MK) oleh Eurico Guterres. Hasilnya, melalui Putusan MK No. 18/PUU-V/2007 MK menyatakan bahwa penjelasan Pasal 43 Ayat (2) UU No. 26 Tahun 2000 mengenai kata "dugaan" bertentangan dengan UUD NRI Tahun 1945 dan tidak memiliki kekuatan hukum mengikat. Kata 'dugaan' dalam penjelasan Pasal 43 Ayat (2) UU No. 26 Tahun 2000 dapat menimbulkan ketidakpastian hukum, maka dengan adanya putusan MK No. 18/PUU-V/2007, DPR tidak boleh serta merta mengajukan usulan atas dugaan DPR sendiri, tanpa memperoleh hasil penyelidikan dan penyidikan dari Komnas HAM dan Kejaksaan Agung dalam membentuk pengadilan HAM Ad Hoc. Lantas pasca putusan MK No. 18/PUU-V/2007, bagaimana usulan DPR dalam Pengadilan HAM Ad Hoc tersebut? Apa DPR wajib membentuk pengadilan HAM Ad Hoc pasca adanya dugaan dari Komnas HAM ataupun Kejaksaan Agung?

\section{RUMUSAN MASALAH}

Berdasarkan Putusan MK No. 18/PUU-V/2007 sebagaimana telah diuraikan di atas, tulisan ini akan membahas terkait ratio decedendi Putusan MK No. 18/PUU-V/2007 dan Usulan DPR dalam pembentukan Pengadilan HAM Ad Hoc pasca Putusan MK No. 18/PUU-V/2007.

\section{METODE PENELITIAN}

Tulisan ini merupakan penelitian argumentasi hukum dengan memfokuskan ciri utama mengkaji pemberlakuan suatu kasus dengan disertai argumentasi/pertimbangan hukum yang dibuat penegak hukum, serta interpretasi di balik pemberlakuan tersebut. ${ }^{\mathbf{1 8}}$ Jenis penelitian yang digunakan adalah penelitian hukum normatif yaitu penelitian hukum kepustakaan, karena menjadikan bahan kepustakaan sebagai tumpuan utama. ${ }^{19}$ Penelitian normatif ini dilakukan dengan mengkaji dan menaganalisa peraturan perundang-undangan ataupun bahan

\footnotetext{
${ }^{17}$ Sri Lestari. "Kasus penembakan mahasiswa Trisakti, Semanggi I dan II, belum selesai setelah 20 tahun reformasi", BBC Indonesia, diakses dari https://www.bbc.com/indonesia/indonesia-43940189, pada tanggal 1 April 2018.

${ }^{18}$ Hoecke, M.V, Legal doctrine: Which method(s) for what kind of discipline?' dalam Hoecke, M.V, (2011), European academy of legal theory of monograph series. (Oxford: HART Publishing,2011),4.

${ }^{19}$ Rahmat GM Manik, "Pemutusan Hubungan Kerja Atas Kesalahan Berat Setelah Pasal 158 UndangUndang Nomor 13 Tahun 2003 Tentang Ketenagakerjaan Dicabut Oleh Putusan Mahkamah Konstitusi Nomor 012/PUU-I/2003", Melayunesia Law 1 no.1 (Desember 2017):69.
} 
hukum lain yang berkaitan dengan kewenangan DPR dalam membentuk pengadilan HAM Ad Hoc, seperti Undang-Undang Nomor 39 Tahun 1999 Tentang Hak Asasi Manusia, UndangUndang Nomor 26 Tahun 2000 Tentang Pengadilan Hak Asasi Manusia, dan sebagainya. Selain itu penelitian hukum normatif ini juga membahas proses pemberlakuan hukum atas suatu kasus hukum, yang prosesnya terdiri dari pembacaan putusan hukum, pertimbangan hakim (ratio decedendi) di balik lahirnya putusan tersebut, dan penggalian pelajaran hukum yang diambil dari putusan dan pertimbangan hukum yang berkaitan dengan usulan DPR dalam pembentukan Pengadilan Ham Ad Hoc, khususnya pasca Putusan MK Nomor 18/PUU/V/2007.

Penelitian ini menggunakan pendekatan pendekatan peraturan perundangundangan (statute approach), pendekatan konseptual (conceptual approach), dan pendekatan kasus (case approach).

Pendekatan perundang-undangan (statute approach) dilakukan dengan menelaah semua peraturan perundang-undangan dan regulasi yang berkaitan dengan dengan isu hukum yang ditangani, sehingga dapat diketahui ratio legis, dasar ontologis dan landasan filosofis pengaturan yang berkaitan tentang pembentukan pengadilan HAM Ad Hoc. ${ }^{20}$ Hal ini dliakukan dengan menganalisis berbagai peraturan yang terkait dengan usulan DPR terkait pembentukan pengadilan HAM Ad Hoc. Pendekatan ini dipilih karena yang akan diteliti adalah berbagai peraturan perundang-undangan yang terkait dengan masalah yang telah dirumuskan, yaitu UU HAM, UU Pengadilan HAM, dsb.

Pendekatan konseptual (conceptual approach) merupakan Pendekatan konseptual beranjak dari pandangan-pandangan dan doktrin-doktrin yang berkembang di dalam ilmu hukum. ${ }^{21}$ Pendekatan ini dilakukan dengan pemahaman atas konsep yang dikemukakan para ahli yang terdapat di berbagai literature terutama yang terkait dengan usulan DPR dalam pembentukan Pengadilan Ham Ad Hoc, khususnya pasca Putusan MK Nomor 18/PUU/V/2007.

Pendekatan kasus (case approach) menggunakan putusan hakim sebagai sumber bahan hukum. ${ }^{22}$ Putusan hakim yang digunakan adalah putusan hakim yang telah memiliki kekuatan hukum tetap. Pada saat membahas putusan pengadilan sebagai bahan hukum primer telah dikatakan bahwa yang memiliki kekuatan hukum adalah pada bagian ratio decidendinya, yaitu alasan hukum yang digunakan oleh hakim dalam menentukan putusannya (pertimbangan hakim) yang tertuang dalam Putusan Mahkamah Konstitusi Nomor 18/PUUV/2007 tentang usulan DPR dalam pembentukan Pengadilan Ham Ad Hoc.

Di lihat dari sifatnya, penelitian ini bersifat deskriptif, yaitu bertujuan menggambarkan secara tepat sifat-sifat suatu individu, keadaan, gejala atau kelompok tertentu, atau untuk menentukan penyebaran suatu gejala, atau untuk menentukan ada tidaknya hubungan antara suatu gejala dengan gejala lain dalam masyarakat. ${ }^{23}$

20 Mukti Fajar dan Yulianto Achmad, Dualisme Penelitian Hukum Normatif dan Empiris, (Yogyakarta:Pustaka Pelajar,2013),95.

${ }^{21}$ Mukti Fajar dan Yulianto Achmad, Dualisme Penelitian Hukum Normatif dan Empiris, 96.

22 Peter Mahmud Marzuki, Penelitian Hukum, (Jakarta : Kencana Prenada Media Group, 2009),93-95.

23 Amirudin dan Zainal Asikin, Pengantar Metode Penelitian Hukum, (Jakarta : Rajawali Press, 2010),25. 
Dalam penelitian hukum normatif sumber datanya adalah data sekunder. Data sekunder pada penelitian ini dibedakan menjadi 3 (tiga):

1) Bahan Hukum Primer yaitu bahan hukum yang bersifat pokok yang menjadi acuan dasar penulisan ini, yaitu semua peraturan perundang-undangan yang berkaitan dengan judul penelitian. Dalam penulisan penelitian ini penulis menggunakan beberapa contoh bahan hukum primer, yakni Putusan MK, UU HAM, UU Pengadilan HAM.

2) Bahan Hukum Sekunder adalah bahan pustaka yang erat hubunganya dengan bahan hukum primer yang dapat membantu menganalisa untuk memahami bahan hukum primer tersebut. Bahan hukum primer ini dapat berupa rancangan undang-undang, hasil penelitian, penerbitan pemerintah, teori-teori hukum, karya tulis dari kalangan ahli hukum dan lain sebagainya. Bahan hukum sekunder yang penulis pergunakan dalam penelitian ini adalah berupa buku, jurnal, dan berbagai penelitian terkait pembentukan pengadilan HAM Ad Hoc oleh DPR.

3) Bahan Hukum Tersier, yaitu bahan-bahan yang memberikan penjelasan yang berkaitan dengan bahan hukum primer dan sekunder. Bahan hukum tersier yang digunakan untuk penelitian ini adalah kamus hukum.

\section{HASIL DAN PEMBAHASAN}

\section{Usulan DPR Berdasarkan Dugaan Sendiri Dalam Pembentukan Pengadilan HAM Ad- Hoc}

Hak Asasi Manusia (HAM) menjadi hal yang sangat mendasar bagi suatu negara untuk melakukan pemenuhan perlindungan kepada warga negaranya. Indonesia merupakan salah satu negara yang mengakui dan menjunjung tinggi HAM dimana pengaturannya diletakkan di dalam konstitusinya sebagaimana telah diatur di dalam BAB XA UUD NRI Tahun 1945. F, Budi Hardiman menjelaskan ratio mengapa manusia membutuhkan perlindungan atas HAM bahwa manusia adalah makhluk yang rentan dan rapuh terhadap kesewenang-wenangan dan kekejaman. Kemungkinan ganda yang dimiliki manusia baik untuk menjadi korban maupun menjadi pelaku kebengisan memunculkan tuntutan universal yang bersumber dari kesadaran manusia sendiri untuk melindungi keringkihan itu. ${ }^{24}$ Pernyataan tersebut selaras dengan kenyataan yang terjadi di Indonesia pada masa Orde Baru yang memperlihatkan pelanggaran HAM berat pada waktu itu sangat rentan dan mudah dilakukan oleh penguasa seperti Kasus Tanjung Priok, Trisakti, Semanggi I dan II, kasus Timor Timur serta beberapa kasus lain yang sampai saat ini belum ada titik terangnya. Muladi menyatakan bahwa pelanggaran HAM berat merupakan salah satu bentuk khusus political crimes yang memiliki nuansa khusus yakni penyalahgunaan kekuasaan dalam arti para pelaku berbuat dalam konteks pemerintahan dan difasilitasi oleh kekuasaan pemerintah sehingga mengandung unsur state action or policy action. ${ }^{25}$

Pelanggaran HAM berat telah diatur di dalam Pasal 7 Undang-Undang Nomor 26 Tahun 2000 tentang Pengadilan HAM yaitu kejahatan genosida dan kejahatan terhadap kemanusiaan dimana dua jenis kejahatan ini dalam hukum internasional menjadi yurisdiksi dari International Criminal Court (ICC) dan berlaku asas universal sehingga ketika suatu negara

24 F. Budi Hardiman, 'Hak-Hak Asasi Manusia: Polemik dengan Agama dan Kebudayaan', Yogyakarta: Kanisius, 2011, hlm.21.

${ }^{25}$ Muladi, "Pengadilan Pidana Bagi Pelanggar HAM Berat di Era Demokrasi”, Jurnal Demokrasi dan HAM, Vol.1 No.1 Mei-Agustus 2000, hlm.41-43. 
tidak dapat menyelesaikan kejahatan yang terjadi dalam negara tersebut, maka masyarakat internasional yaitu semua negara dapat melakukan penindakan atas kejahatan tersebut melalui ICC oleh anggota Statuta Roma, Jaksa Penuntut, dan Dewan Keamanan PBB. ${ }^{26}$

Criminal justice process terhadap kasus pelanggaran HAM berat yang terjadi setelah diundangkannya Undang-Undang Pengadilan HAM diselesaikan melalui Pengadilan HAM berdasarkan pada Risalah Rapat Pansus RUU tentang Pengadilan HAM pada tanggal 2 November 2000 dimana dimulai dari tahap penyelidikan yang dilakukan oleh Komnas HAM dengan membntuk tim ad hoc, penyidikan dan penuntutan yang dilakukan oleh Jaksa Agung, serta diperiksa dan diadili di Pengadilan HAM dengan Majelis Hakim sejumlah lima orang dengan komposisi dua orang hakim pada pengadilan HAM dan tiga orang hakim ad hoc sesuai Pasal 27 Undang-Undang Pengadilan HAM.

Selain mengadili kasus pelanggaran HAM berat yang bersifat prospektif, pengadilan HAM juga melakukan pengadilan terhadap kasus pelanggaran HAM berat yang bersifat retroaktif. ${ }^{27}$ Berdasarkan Pasal 43 ayat (1) UU No. 26 Tahun 2000, pelanggaran HAM berat yang terjadi sebelum diundangkannya UU No. 26 Tahun 2000, diperiksa dan diputus oleh Pengadilan HAM Ad Hoc. Pengadilan HAM Ad Hoc dibentuk atas usul DPR berdasarkan peristiwa tertentu dengan Keputusan Presiden. ${ }^{28}$ Untuk menentukan ada atau tidaknya pelanggaran HAM berat, berdasarkan pada Penjelasan Pasal 43 ayat (1) UU No. 26 Tahun 2000, DPR mendasarkan pada dugaan telah terjadinya pelanggaran HAM yang berat yang dibatasi pada locus dan tempus delicti yang terjadi sebelum diundangkannya undang-undang ini. $^{29}$

Berdasarkan Penjelasan Pasal Pasal 43 ayat (1) UU No. 26 Tahun 2000 yang memberikan kewenangan kepada DPR untuk melakukan dugaan, berarti menunjukkan bahwa DPR haruslah memberikan penilaian (judgement) terlebih dahulu sebelum mengajukan usul pembentukan Pengadilan HAM Ad Hoc mengenai ada atau tidaknya pelanggaran HAM berat di masa lampau. Hal ini, seolah-olah DPR telah melakukan fungsi penegak hukum. Padahal ketika melihat frasa dugaan tersebut, secara normatif dalam Pasal 1 angka 5 UU No. 26 Tahun 2000, dijelaskan bahwa:

"Penyelidikan adalah serangkaian tindakan penyelidik untuk mencari dan menemukan ada tidaknya suatu peristiwa yang diduga merupakan pelanggaran hak asasi manusia yang berat guna ditindaklanjuti dengan penyidikan sesuai dengan ketentuan yang diatur dalam Undang-undang ini." ( penebalan oleh penulis).

Sehingga berdasarkan Pasal 1 angka 5 UU No. 26 Tahun 2000, maka dugaan merupakan suatu bagian dari sebuah tindakan hukum penyelidikan. Mengenai kewenangan penyelidikan tersebut tidak dimiliki oleh DPR, namun sejatinya terkait penyelidikan khusus terkait pelanggaran HAM berat itu dimiliki oleh Komnas HAM, sesuai Pasal 18 ayat (1) UndangUndang Pengadilan HAM. Dalam penjelasan Pasal 18 ayat (1) UU No. 26 Tahun 2000, juga dijelaskan bahwa:

\footnotetext{
${ }^{26}$ Koalisi Masyarakat Sipil untuk Mahkamah Pidana Internasional, 'Mengenal ICC Mahkamah Pidana Internasional', Jakarta Pusat: Sentralisme Production, 2009, hlm.7-9.

27 Prospektif artinya terjadi setelah Undang-Undang disahkan, sementara retroaktif artinya terjadi sebelum Undang-Undang disahkan.

${ }^{28}$ Undang-Undang Nomor 26 Tahun 2000 tentang Pengadilan Hak Asasi Manusia (Lembaran Negara Tahun 2000 Nomor 208, Tambahan Lembaran Negara Nomor 4026).

${ }^{29}$ Ibid.
} 
"Kewenangan penyelidikan hanya dilakukan oleh Komisi Nasional Hak Asasi Manusia dimaksudkan untuk menjaga objektivitas hasil penyelidikan karena lembaga Komisi Nasional Hak Asasi Manusia adalah lembaga yang bersifat independen"

Berdasarkan penjelasan Pasal 18 ayat (1) UU No. 26 Tahun 2000, dapat dilihat bahwa alasan Komnas HAM sebagai satu-satunya yang diberi kewenangan untuk melakukan penyidikan dalam rangka melakukan dugaan adanya pelanggaran HAM berat adalah untuk menjaga objektivitas akan hasil penyelidikan. Selain itu mengacu pendapat Bernard L. Tanya, bahwa penunjukan lembaga Komnas HAM sebagai penyelidik terhadap peristiwa- peristiwa tindak pidana pelanggaran HAM yang berat merupakan salah satu bentuk kehati-hatian dan rasionalitas penggunaan dan penerapan hukum pidana karena tiga alasan sebagai berikut: ${ }^{30}$

1. Secara fungsional, Komnas HAM memang suatu Lembaga Negara yang bertugas melakukan pemantauan tentang hak asasi manusia, sehingga sesuai dengan wewenang penyelidikan yang diembannya;

2. Komnas HAM beranggotakan tokoh masyarakat yang profesional, berdedikasi dan berintegritas tinggi, menghayati cita-cita negara hukum dan negara kesejahteraan yang berintikan keadilan, menghormati hak asasi manusia dan kewajiban dasar manusia. Dengan demikian sebagai penyelidik, profesionalisne, kapabilitas, dan kredibilitasnya benar-benar dapat terjaga;

3. Kedudukan Komnas HAM sebagai lembaga mandiri yang setingkat dengan lembaga negara Iainnya, menutup kemungkinan intervensi dari pihak manapun;

Berdasarkan pada hal tersebut, maka dapat dilihat bahwa Komnas HAM merupakan lembaga yang independen dan kredibel. Justru ketika kewenangan menduga-duga yang merupakan rana penyelidikan ini juga diberikan kepada DPR yang sarat akan kepentingan politik, maka akan menyebabkan minimnya objektivitas dalam dugaan tersebut. Sejatinya dengan memberikan kewenangan terkait dugaan kepada DPR itu, maka akan menciptakan tumpang tindih kewenangan (overlay) antara DPR dan Komnas HAM.

Selain itu, dengan mendasarkan pada dugaan dari DPR sendiri, maka laporan atau rekomendasi dari lembagai lain, seperti Komnas HAM, seolah hanyalah merupakan kebiasaan dalam praktik belaka dan bukan merupakan suatu aturan yang mengikat. Dengan kata lain, DPR dapat mengajukan usul pembentukan Pengadilan HAM Ad Hoc bilamana menurut dugaan telah terjadi pelanggaran HAM berat, tanpa harus mengikut sertakan lembaga lain. Hal ini seoah-olah menderogasi fungsi penyelidikan yang dimiliki oleh Komnas HAM sesuai Pasal 18 ayat (1) UU No. 26 Tahun 2000. Sehingga ketika beranjak pada teori Jimly Ashidiqie terkait kriteria konstitusionalitas dari Undang-Undang yaitu sejauh mana undangundang itu ditetapkan dalam bentuk yang tepat (appropriate form), oleh institusi yang tepat (appropriate institution), dan menurut prosedur yang tepat (appropriate procedure), ${ }^{31}$ maka dengan diletakannya kewenangan "menduga-duga" kepada DPR, maka bisa dikatakan Undang-Undang tersebut tidaklah konstitusional, karena tidak berada pada institusi yang tepat.

\footnotetext{
${ }^{30}$ Putusan Mahkamah Konstitusi No. 18/PUU-V/2007, tanggal 21 Februari 2008, hlm.53.

31 Jimly Asshiddiqie, Pengantar Ilmu Hukum Tata Negara (Jakarta: Sekretariat Jendral Mahkamah Konstitusi, 2006), 62-67.
} 
Selain itu Undang-Undang UU No. 26 Tahun 2000 juga tidak mengatur DPR sebagai lembaga penegakan hukum (pidana). Hal itu dapat dilihat dalam ketentuan pasal-pasal dalam UU No. 26 Tahun 2000 yang menyebutkan bahwa yang berwenang:

a) melakukan penyelidikan adalah Komisi Nasional Hak Asasi Manusia (Pasal 1820);

b) bidang penyidikan dilakukan oleh Jaksa Agung (Pasal 21-22); dan

c) bidang penuntutan dilakukan oleh Jaksa Agung (Pasal 23-25).

Sejatinya, yang dipermasalahkan bukanlah peran serta DPR dalam membentuk Pengadilan HAM Ad Hoc. Karena memang untuk kasus pelanggaran HAM berat yang bersifat retrokatif, dimana mengesampingkan asas non-retroaktif di dalam Pasal 1 ayat (1) Kitab Undang-Undang Hukum Pidana (KUHP), sehingga memang diperlukan kebijakan yang bersifat khusus. ${ }^{32}$ Namun bukan berarti hal tersebut memberikan justifikasi agar terdapat keharusan bagi DPR untuk melakukan penilaian yang bersifat menghakimi tentang suatu peristiwa hukum pidana. Peran DPR seharusnya tetap dalam mengajukan usulan adanya pelanggaran HAM berat yang bersifat retroaktif, namun dalam pengajuan tersebut, bukan didasarkan oleh dugaan DPR sendiri, namun didasarkan pada penyelidikan Komnas HAM itulah, DPR mengajukan usulan kepada Presiden. Sehingga peran DPR hanya menimbangnya secara politis. Ini pun merupakan konsekuensi yuridis, karena Undang-Undang Pengadilan HAM yang merupakan produk legislasi menetapkan Komnas HAM sebagai satu-satunya lembaga penyelidik pelanggaran HAM yang berat.

\section{Usulan Dpr Dalam Pembentukan Pengadilan HAM Ad-Hoc Pasca Putusan MK Nomor 18/PUU-V/2007}

Mahkamah Konstitusi mengeluarkan Putusan No. 18/PUU-V/2007 pada tanggal 21 Februari 2008 tentang Pembentukan Pengadilan HAM Ad Hoc atas usulan DPR yang dimohonkan oleh Eurico Guterres dimana pokok permohonannya berkaitan dengan kata "dugaan” di dalam Pasal 43 ayat (2) UU No. 26 Tahun 2000 serta penjelasannya yang mengatur bahwa DPR mengusulkan dibentuknya Pengadilan HAM Ad Hoc yang didasarkan pada dugaan telah terjadinya pelanggaran HAM yang berat yang dibatasi pada locus dan tempus delicti yang terjadi sebelum diundangkannya undang-undang ini ${ }^{33}$. Dengan demikian, sebelum DPR mengusulkan dibentuknya pengadilan HAM Ad Hoc, maka DPR telah melakukan dugaan terlebih dahulu bahwa telah terjadi pelanggaran HAM yang berat sebelum mengajukan usul pembentukkan Pengadilan HAM Ad Hoc sehingga DPR telah melakukan fungsi pengadilan (kekuasaan kehakiman) yang didasarkan atas dugaannya ${ }^{34}$ dimana hal ini bertentangan dengan konstalasi Montesquieu tentang pemisahan kekuasaan yang dianut oleh sistem ketatanegaraan Indonesia yaitu lembaga legislatif, eksekutif, dan yudisiil. ${ }^{35}$ Pemisahan

32 Hukumonline. "Asas Non Retroaktif”, hukumonline, diakses dari https://www.hukumonline.com/klinik/detail/ulasan/lt4c80ae57a77f0/asas-non-retroaktif, pada tanggal 12 April 2018.

33 Ibid.

${ }^{34}$ Putusan Mahkamah Konstitusi No. 18/PUU-V/2007, tanggal 21 Februari 2008, hlm.101.

35 Firmansyah Arifin Dkk, 'Lembaga Negara dan Sengketa Kewenangan Antarlembaga Negara', KRHN Bekerjasama dengan MKRI, The Asia Foundation dan USAID, Jakarta, 2005, hlm.29. 
kekuasaan mengandung pengertian bahwa tiap cabang kekuasaan harus dipegang oleh pejabat yang berbeda dan tidak boleh merangkap jabatan cabang kekuasaan lain. ${ }^{36}$

Dugaan yang dilakukan oleh DPR menjadikan DPR harus melakukan upaya penyelidikan dimana tahapan itu sudah masuk ke dalam criminal justice process. Menurut Andi Hamzah bahwa sistem bekerjanya hukum acara pidana dimulai pada tahap mencari kebenaran, penyelidikan, penyidikan, dan berakhir pada pelaksanaan pidana atau eksekusi oleh jaksa. Pendapat tersebut sejalan dengan Joan Miller yang merupakan Guru Besar dari Amerika Serikat yang disampaikan pada waktu menjadi pembicara dalam Lokakarya Criminal Justice System di Universitas Indonesia yang menyatakan bahwa operasionalisasi sistem peradilan pidana dimulai sejak pembentukkan undang-undang pidana di DPR sampai pada pembinaan narapida hingga bebas dari penjara. Oleh karena itu, DPR merupakan bagian dari criminal justice system bukan criminal justice process yang seharusnya menjadi kewenangan dari Komnas HAM, Jaksa Agung, dan Hakim pada Pengadilan HAM Ad Hoc.

Melalui Keterangan DPR, Pemerintah menyatakan bahwa Pengadilan HAM Ad Hoc, baik bentuk institusi maupun prosedurnya telah sesuai dengan peraturan perundang-undangan yang berlaku dimana pengusulan pembentukan Pengadilan HAM Ad Hoc dari DPR sebagai representasi kehendak rakyat Indonesia dan dalam rangka menjalankan fungsi pengawasan, kemudian dibentuk dengan Keputusan Presiden karena mengatur hal yang bersifat penetapan atas pembentukan Pengadilan HAM Ad Hoc dalam kasus atau peristiwa tertentu. ${ }^{37}$

Berbeda halnya dengan pembentukan Pengadilan HAM yang relatif bebas dari pertimbangan-pertimbangan politik karena ditujukan bagi penyelesaian pelanggaran HAM yang berat yang terjadi pada masa yang akan datang. Sedangkan pembetukan Pengadilan HAM Ad Hoc tujuan pembentukannya adalah sebagai bagian dari upaya penyelesaian persoalan transnational justice yaitu mengadili pelaku pelanggaran hak asasi manusia yang berat yang terjadi masa lalu Selain itu, pembentukan Pengadilan HAM Ad Hoc justru merupakan keputusan politik karena tujuan pembentukannya adalah untuk menyelesaikan pelanggaran HAM yang berat yang terjadi pada masa lampau dan sifatnya alternatif. ${ }^{38}$ Walaupun pembentukan Pengadilan HAM Ad Hoc adalah sebuah keputusan politik, untuk menjaga keseimbangan antara kepentingan politik, kepentingan hukum, dan tuntutan rasa keadilan agar tidak menjadi sewenang-wenang, maka dilakukan pembatasan bukan hanya terhadap jenis perbuatan yang menjadi kompetensi mengadili atau ratione materiae dari Pengadilan HAM Ad Hoc yang dibentuk itu, tetapi juga pembatasan terhadap locus delicti dan tempus delicti dari perbuatan yang masuk dalam ratione materiae Pengadilan HAM Ad Hoc tersebut yang dilakukan melalui proses penyelidikan yang mendalam. ${ }^{39}$

Hal tersebut juga digunakan oleh hukum internasional dimana dibentuk Pengadilan Ad Hoc yaitu International Criminal Tribunal for the former Yugoslavia atau ICTY berdasarkan Resolusi Dewan Keamanan PBB No. 808/1993 ${ }^{40}$ dan International Criminal Tribunal for Rwanda atau ICTR berdasarkan Resolusi Dewan Keamanan PBB No. 955/1994 yang merujuk pada Bab VII Charter PBB. ${ }^{41}$ yang berarti resolusi ini merupakan sebuah keputusan politk. Namun, DPR tidak mampu menentukan kriteria-kriteria yang jelas dan konsisten untuk dapat

\footnotetext{
${ }^{36}$ Montesquieu, 'The Spirit of Law', translated by Thomas Nugent, New York: Hafner Press, 1949, hlm. 151.

${ }^{37}$ Putusan Mahkamah Konstitusi No. 18/PUU-V/2007, tanggal 21 Februari 2008, hlm.20.

${ }^{38}$ Putusan Mahkamah Konstitusi No. 18/PUU-V/2007, tanggal 21 Februari 2008, hlm.100.

${ }^{39}$ Putusan Mahkamah Konstitusi No. 18/PUU-V/2007, tanggal 21 Februari 2008, hlm.100.

40 Geoffrey Robertson QC, 'Kejahatan terhadap Kemanusiaan Perjuangan untuk Mewujudkan Keadilan Global', editor Suhartono, Komisi HAM, Jakarta, 2002, hlm.351.

${ }^{41}$ Made Pasek Diantha, 'Hukum Pidana Internasional', Jakarta: Prenada Media, 2014, hlm.83.
} 
mengkualifikasikan pelanggaran HAM berat ke dalam ratione materiae Pengadilan HAM Ad Hoc dalam melakukan penilaian dan hasilnya berbeda-beda seperti kasus Tanjung Priok, Trisakti, Semanggi I dan II, Talangsari, dan Operasi Anti Terorisme di Poso yang terjadi pada awal tahun 2007. ${ }^{42}$ Berbeda jika dibandingkan dengan rumusan norma yang terdapat dalam ICTY dan ICTR dimana mempunyai kualifikasi yang jelas dan konsisten dimana yurisdiksi materi dari ICTY meliputi kejahatan terhadap kemanusiaan yang hanya apabila dilakukan di dalam suatu konflik bersenjata yaitu kejahatan yang dilakukan di wilayah Yugoslavia sejak tahun $1991 .{ }^{43}$ Sedangkan yurisdiksi materi dalam ICTR adalah genosida dan kejahatan terhadap kemanusiaan yang dilakukan antara tanggal 1 Januari sampai dengan 31 Desember $1994 .{ }^{44}$

Majelis Hakim Mahkamah Konstitusi memberikan pertimbangan bahwa Pengadilan HAM Ad Hoc dibentuk hanya terhadap peristiwa-peristiwa tertentu yaitu bukan terhadap semua peristiwa, melainkan hanya terhadap peristiwa-peristiwa yang locus delicti dan tempus delictinya dibatasi sebagaimana disebutkan dalam Penjelasan Pasal 43 ayat (2) UU No. 26 Tahun 2000. Pengadilan HAM Ad Hoc hanya dapat dibentuk atas usulan DPR sebagai representasi rakyat Indonesia dimana pada dasarnya rakyat lah yang sesungguhnya berhak menentukan kapan suatu pelanggaran HAM yang berat telah terjadi. ${ }^{45}$ Dalam merekomendasikan pembentukan Pengadilan HAM Ad Hoc, DPR harus memperhatikan hasil penyelidikan oleh Komnas HAM dan hasil penyidikan oleh Jaksa Agung sesuai ketentuan Undang-Undang Pengadilan HAM sehingga DPR tidak akan serta merta menduga tanpa memperoleh atau memiliki hasil penyelidikan dan penyidikan dari kedua institusi tersebut. ${ }^{46}$ Oleh karena itu Mahkamah Konstitusi menyatakan bahwa kata "dugaan" dalam Penjelasan Pasal 43 ayat (2) UU No. 26 Tahun 2000 bertentangan dengan Konstitusi dan tidak mempunyai kekuatan hukum mengikat.

Meskipun dalam Putusan MK No. 18/PUU-V/2007 telah menghapus frasa dugaan yang ada pada penejalasan Pasal 43 ayat (2) UU No. 26 Tahun 2000, di dalamnya terdapat pendapat yang berbeda dari I Gede Dewa Palguna. Di dalam putusan MK No. 18/PUUV/2007, I Gede Dewa Palguna menyatakan dissenting opinion yang isinya adalah bahwa kewenangan Komnas HAM dalam melakukan Penyelidikan diberikan oleh Undang-Undang dalam rangka criminal justice process di Pengadilan HAM bukan di Pengadilan HAM Ad Hoc sehingga dengan kata lain Komnas HAM tidak mempunyai kewenangan untuk melakukan penyelidikan terhadap pelanggaran HAM yang berat yang terjadi sebelum diundangkannya Undang-Undang Pengadilan HAM. ${ }^{47}$ Dikarenakan keberadaan Pengadilan HAM Ad Hoc adalah dalam rangka penyelesaian persoalan transnational justice, maka keputusan untuk menentukan siapa yang akan diberikan kewenanangan melakukan penyelidikan adalah sebuah keputusan politik agar keputusan politik tersebut tidak sewenang-wenang, maka kewenangan penyelidikan itu tidak boleh dipegang sendiri oleh DPR, melainkan harus dilakukan oleh suatu institusi yang independen. Misalnya keputusan politik tersebut menunjuk Komnas HAM sebagai Penyelidik. Namun dalam demikian, kewenangan Komnas HAM untuk melakukan peyelidikan tersebut bukanlah lahir dari Pasal 18 ayat (1) Undang-Undang Pengadilan HAM, melainkan sebagai hasil dari keputusan politik DPR. ${ }^{48}$

\footnotetext{
${ }^{42}$ Putusan Mahkamah Konstitusi No. 18/PUU-V/2007, tanggal 21 Februari 2008, hlm.43.

${ }^{43}$ Muladi, 'Peradilan HAM dalam Konteks Nasional dan Internasional'

${ }^{44}$ Anis Widyawati, 'Hukum Pidana Internasional', Jakarta: Sinar Grafika, 2014, hlm.149.

${ }^{45}$ Putusan Mahkamah Konstitusi No. 18/PUU-V/2007, tanggal 21 Februari 2008, hlm.91

${ }^{46}$ Putusan Mahkamah Konstitusi No. 18/PUU-V/2007, tanggal 21 Februari 2008, hlm.94.

${ }^{47}$ Putusan Mahkamah Konstitusi No. 18/PUU-V/2007, tanggal 21 Februari 2008, hlm.104.

${ }^{48}$ Putusan Mahkamah Konstitusi No. 18/PUU-V/2007, tanggal 21 Februari 2008, hlm.104.
} 
Hasil dari putusan MK No. 18/PUU-V/2007 yang menyatakan bahwa dalam merekomendasikan pembentukan Pengadilan HAM Ad Hoc, DPR harus memperhatikan hasil penyelidikan oleh KOMNAS HAM dan hasil penyidikan oleh Jaksa Agung sesuai ketentuan Undang-Undang Pengadilan HAM sehingga DPR tidak akan serta merta menduga tanpa memperoleh atau memiliki hasil penyelidikan dan penyidikan dari kedua institusi tersebut. Namun, akan timbul pertanyaan apakah ketika telah ada dugaan pelanggaran HAM yang berat yang terjadi sebelum diundangkannya Undang-Undang Pengadilan HAM dari hasil penyelidikan Komnas HAM dan hasil penyidikan Jaksa Agung maka DPR harus memberikan usul atau rekomendasi kepada Presiden untuk kemudian dikeluarkan Keputusan Presiden? Karena hanya akan menjadi sia-sia jika DPR tidak mempunyai kewajiban untuk memberikan usul kepada Presiden seperti dalam kondisi sebelum dikeluarkannya Putusan ini dimana akan terjadi suatu ketimpangan lagi ketika KOMNAS HAM dan Jaksa Agung menduga telah pelanggaran HAM yang berat yang terjadi sebelum diundangkannya Undang-Undang Pengadilan HAM, tetapi ternyata DPR tidak menyampaikan usul kepada Presiden dengan argumentasi bahwa DPR menilai tidak ada pelanggaran yang dimaksud terjadi.

M. Mahendradatta, S.H.,MA.,MH.PhD yang merupakan Kuasa Hukum dari Pemohon Putusan MK No. 18/PUU-V/2007 menafsirkan dari putusan tersebut dan menyatakan bahwa fungsi DPR saat ini hanya menjadi "stempel" dikarenakan mau tidak mau bila KOMNAS HAM telah menyelidik dan Jaksa Agung telah menyidik sehingga telah terdapat dugaan terjadinya pelanggaran HAM yang berat yang terjadi sebelum diundangkannya UndangUndang Pengadilan HAM, maka DPR harus membentuk Pengadilan HAM Ad Hoc. ${ }^{49}$ Namun, Kejaksaan Agung ketika Kapuspenkum dipegang oleh Salman mariyadi menyatakan bahwa Kejaksaan Agung akan memulai penyidikan apabila telah dikeluarkan izin dari DPR dengan argumentasi bahwa penyelidikan, penyidikan, dan penuntutan dinilai dari hukum acara yang memerlukan izin DPR sehingga penyidikan harus diawali dengan rekomendasi DPR. ${ }^{50}$

Sistem peradilan pidana dimulai sejak pembentukkan undang-undang pidana di DPR sampai pada pembinaan narapida hingga bebas dari penjara sehingga DPR merupakan bagian dari criminal justice system bukan criminal justice process dikarenakan DPR hanya mempunyai kewenangan membuat undang-undang saja dalam criminal justice system. Sejalan dengan itu, Dr. M. Sholehuddin, S.H., M.H, ahli dalam bidang Sistem Peradilan Pidana menyatakan bahwa sebaiknya tidak dibutuhkan keterlibatan DPR dalam subsistem yudisiil dikarenakan kewenangan DPR dalam lingkup sistem peradilan pidana tetap dibutuhkan sebatas membuat undang-undang saja sehingga ketika DPR bertindak di luar batasan itu maka akan terjadi pelampauan beban tugas, overlapping kewenangan yang berakibat menimbulkan kesewenang-wenangan. ${ }^{51}$

\section{KESIMPULAN}

Berlakunya Putusan MK No. 18/PUU-V/2007 memberikan norma hukum baru yaitu dalam merekomendasikan pembentukan Pengadilan HAM Ad Hoc, DPR harus memperhatikan hasil penyelidikan oleh KOMNAS HAM dan hasil penyidikan oleh Jaksa Agung sesuai ketentuan Undang-Undang Pengadilan HAM sehingga DPR tidak akan serta merta menduga tanpa memperoleh atau memiliki hasil penyelidikan dan penyidikan dari kedua institusi tersebut. Oleh karena itu Mahkamah Konstitusi menyatakan bahwa kata

${ }^{49}$ Ali, "DPR Tak Bisa Lagi Tentukan Sendiri Dugaan Pelanggaran HAM”. www.hukumonline,com, 21 Februari 2008, dikunjungi pada tanggal 20 Mei 2019.

${ }^{50}$ Ibid.

51 NNC, "Campur Tangan Politik Dalam Pembentukan Pengadilan HAM Ad Hoc Beresiko", www.hukumonline,com, 1 November 2007, dikunjungi pada tanggal 20 Mei 2019. 
"dugaan" dalam Penjelasan Pasal 43 ayat (2) bertentangan dengan Konstitusi dan tidak mempunyai kekuatan hukum mengikat. Namun, agar norma hukum baru tersebut bernilai pragmatis sesuai dengan asas finding the law, maka apabila telah ada dugaan pelanggaran HAM yang berat yang terjadi sebelum diundangkannya Undang-Undang Pengadilan HAM dari hasil penyelidikan Komnas HAM dan hasil penyidikan Jaksa Agung, DPR harus memberikan usul atau rekomendasi kepada Presiden untuk kemudian dikeluarkan Keputusan Presiden sehingga akan terwujud kepastian hukum.

\section{DAFTAR PUSTAKA:}

\section{Buku-Buku}

R. Wiyono. Pengadilan Hak Asasi Manusia. Jakarta: Penerbit Kencana, 2006.

F. Budi Hardiman. Hak-Hak Asasi Manusia: Polemik Dengan Agama Dan Kebudayaan. Yogyakarta: Penerbit Kanisius. 2011.

Koalisi Masyarakat Sipil Untuk Mahkamah Pidana Internasional. Mengenal ICC Mahkamah Pidana Internasional. Jakarta Pusat: Penerbit Sentralisme Production. 2009.

Firmansyah Arifin Dkk. Lembaga Negara Dan Sengketa Kewenangan Antarlembaga Negara: KRHN Bekerjasama Dengan MKRI. Jakarta: The Asia Foundation Dan USAID. 2009.

Montesquieu. The Spirit Of Law. Translated By Thomas Nugent. New York: Hafner Press. 1949.

Geoffrey Robertson QC. Kejahatan Terhadap Kemanusiaan Perjuangan Untuk Meweujudkan Keadilan Global. Editor Suhartono. Jakarta: Komisi HAM. 2002.

Made Pasek Diantha. Hukum Pidana Internasional. Jakarta: Penerbit Prenada Media. 2014.

Muladi. Peradilan HAM Dalam Konteks Nasional Dan Internasional.

Nunik Nurhayati. Op. Cit.

Anis Widyawati. Hukum Pidana Internasional. Jakarta: Penerbit Sinar Grafika. 2014.

\section{Jurnal}

Tomy Michael. "Korelasi Aline Keempat Undang-Undang Dasar NRI Tahun 1945 Dengan Pemikiran Immanuel Kant.” Jurnal Hukum Samudra Keadilan, Vol.11 No.2 Juli-Desember 2016.

Nunik Nurhayati. "Quo Vadis Perlindungan Hak Asasi Manusia Dalam Penyelesaian Pelanggaran HAM Berat Masa Lalu Melalui Jalur Non Yudisial.” Jurisprudence, Vol.6 No.2 September 2016.

Fadli Andi Natsif. "Perspektif Keadilan Transisional Penyelesaian Pelanggaran Hak Asasi Manusia Berat.” Jurisprudence, Vol.3, No.2 Desember 2016.

Daniel Hutagalung. "Negara dan Pelanggaran HAM Masa Lalu: Tuntutan Pertanggungjawaban Versus Impunitas.” Jurnal Dignitas, Vol.3 No.1 2005.

Dielaborasi dari Muladi. "Pengadilan Pidana Bagi Pelanggar HAM Berat Di Era Demokrasi." Jurnal Demokrasi Dan HAM, Vol.1 No.1 Mei-Agustus 2000.

\section{Peraturan Perundang-Undangan}

Undang-Undang Nomor 39 Tahun 1999 tentang Hak Asasi Manusia (Lembaran Negara Tahun 1999 Nomor 165, Tambahan Lembaran Negara Nomor 3886).

Undang-Undang Nomor 26 Tahun 2000 tentang Pengadilan Hak Asasi Manusia (Lembaran Negara Tahun 2000 Nomor 208, Tambahan Lembaran Negara Nomor 4026). 


\section{Putusan}

Putusan Mahkamah Konstitusi No. 18/PUU-V/2007. 21 Februari 2008.

\section{Internet}

NNC, "Campur Tangan Politik Dalam Pembentukan Pengadilan HAM Ad Hoc Beresiko", www.hukumonline,com, 1 November 2007, dikunjungi pada tanggal 20 Mei 2019.

Ali, "DPR Tak Bisa Lagi Tentukan Sendiri Dugaan Pelanggaran HAM". www.hukumonline,com, 21 Februari 2008, dikunjungi pada tanggal 20 Mei 2019. 